\title{
Performance measurement of receivable accounts' risk management: A case study of Tehran Stock Exchange
}

\author{
Mohammad Ahmadi $^{a^{*}}$, Abbas Ali Pouraghajan ${ }^{a}$ and Seyed Hassan Salehnezhad ${ }^{\mathrm{b}}$
}

${ }^{a}$ Department of Accounting, Science and Research Branch,Islamic Azad University, Mazandaran, Iran

${ }^{b}$ Department of Accounting, Payame Noor University, Iran

\section{H R O N I C L E}

Article history:

Received January 25, 2013

Received in revised format

17 May 2013

Accepted May 182013

Available online

May 202013

Keywords:

Risk assessment

Tehran Stock Exchange

Drug industry

\section{A B S T R A C T}

This paper presents a logistic regression model to measure risk management of receivable accounts on some selected firms from drug industry listed on Tehran Stock Exchange. The proposed study of this paper considers the effects of different variables such as current ratio, quick ratio, working capital on total assets and cash flow on economic value added. We gather the necessary information of 29 firms over the period 2006-2011. The results of our survey indicate that the proposed model of this paper is capable of forecasting high profit firms with a probability of $87.5 \%, 58.62 \%$ is the likelihood of predicting less profitable firms and on average, the firm could forecast profitable firms for $75.54 \%$, successfully.

(C) 2013 Growing Science Ltd. All rights reserved.

\section{Introduction}

Risk assessment is one of the most important issues among investors especially those people who wish to make big acquisitions on shares of firms listed on different stock exchange. Hajnoori et al. (2013), for instance, calculated the return and risk of each asset and portfolio optimization model based on cardinality constraint and investment income per share and they used Invasive Weed Optimization (IWO) algorithm to solve the resulted model. Dehaghani et al. (2013) presented an empirical investigation to measure the impacts of privatization on some selected firms listed on Tehran Stock Exchange. They selected eleven relatively big sized Iranian firms whose structures were privatized prior year 2011. The main hypothesis of this survey was on whether there was any meaningful relationship between ownership structure and enterprise value of privatized firms. They collected the necessary information before and after privatization process completed and using a regression model investigated the main hypothesis as well as five sub-hypotheses. They reported that the number of major shareholders had been reduced after privatization process accomplished, the number of shares had no impact on firms' values. 
Besides, non-board members' duty had no effects on firms' value before and after privatization process, institutional investors did not play essential role before and after privatization process, and separations played important role on firms' value before and after privatization occurred. Valahzaghard and Mirzamomen (2013) presented a study to measure the relationship between top management turnover with earnings management and default risk and earnings forecast error in the Tehran Stock Exchange. They reported that there were some meaningful relationships between change in top management with earning management, default risk and earning forecast error. Esfahani and Ghasanfarymojarad (2013) studied the relationship between the capital structure and performance of the production market in some firms listed on Tehran Stock Exchange. In this research, the index of capital structure was debt ratio and that of production market performance was sales growth and return of assets (ROA). They reported that there was a strong and significant relationship between debt ratio and return on assets among the companies listed on TSE and most industries especially based metals at the confidence level of 95\%. In contrast, there was no strong and significant relationship between debt ratio and sales growth in the above-mentioned companies and in most industries.

Aghasi et al. (2013) investigated the relationship between bank interest rates on performance of stock exchange over the period 2001-2010. They categorized interest rates into five various categories including short-term interest rate, special short-term rate, one-year, two-year, three-year, four-year and five-year terms. The results of performing regression analysis confirmed that there were some positive and meaningful relationship between interest rate in all groups and performance of stock exchange. Hassani and Misaghi (2013) investigated the relationship between capital employed efficiency and operating cash flow. They reported that there was a positive and significant relationship between capital employed efficiency and operational cash flow. In other words, more cash flow from operational was created through increasing the amount of value added based on capital employed.

Emamgholipour et al. (2013) investigated the relationship between institutional investors and earnings management on some listed companies on Tehran Stock Exchange by studying a sample of 700 firm-years data over the period 2006-2010. They reported that there was a positive and significant relationship between institutional investors and earnings management and suggested that increasing the ownership percentage of institutional shareholders increases earnings management. In addition, the results of the control variables indicated that firm size had no effect on earnings management, but financial leverage and return on sales, respectively had negative and positive impact on the earnings management of companies.

\section{The proposed model}

The proposed study of this paper uses logistic method for measuring the performance of receivable accounts in terms of risk management as follows,

$Z=\operatorname{Ln}\left(\frac{P i}{1-P i}\right)=\beta 0+\sum_{i=1}^{n} \beta+X i$

The proposed model of this paper measures the likelihood of profitability under some special circumstances as follows,

$\mathrm{P}_{\mathrm{i}}=\pi_{\mathrm{i}}\left(X_{1}, X_{2}, \ldots X_{k}\right)=\frac{e^{\beta 0+\sum_{i=1}^{k} \beta 0 X i}}{1+e^{\beta 0+\sum_{i=1}^{k} \beta 0 X i}}$, 
where $X i$ represents independent variables and $P_{i}$ is the likelihood of profitability, which is estimated based on logistic regression techniques. Independent variables include different financial ratios, which are explained as follows,

\subsection{Current ratio(CR)}

Current ratio is calculated based on current assets and liabilities as follows,

Current ratio $(\mathrm{CR})=\frac{\text { Current assets }}{\text { Current liabilities }}$.

\subsection{Quick ratio $(Q R)$}

Quick ratio is calculated based on current assets and liabilities as follows,

Quick ratio $(\mathrm{QR})=\frac{\text { Current assets - Inventories }}{\text { Current liabilities }}$.

2.3. Working capital on total assets (WCTA)

The ratio of working capital on total assets is calculated as follows,

The ratio of working capital on total assets $($ WCTA $)=\frac{\text { Current assets }- \text { Current liabilities }}{\text { Total assets }}$.

\subsection{Cash flow ratio (CFR)}

Cash flow ratio is calculated as follows,

The ratio of cash flow $(\mathrm{CFR})=\frac{\text { Free cash flow }}{\text { Total liabilities }}$.

There two types of cash flow in our survey, which are calculated as follows,

The ratio of cash flow type $1\left(\right.$ FCF1) $=\frac{\text { Operating cash flow } \pm \text { Investment cash flow }}{\text { Total liabilities }}$.

The ratio of cash flow type $2\left(\right.$ FCF2) $=\frac{\text { Total operating cash flow }}{\text { Total liabilities }}$.

2.5. Debt to equity ratio (DE)

Debt-to-equity ratio is calculated as follows,

Debt to equity $(\mathrm{DE})=\frac{\text { Total liabilities }}{\text { Total equities }}$.

2.6. Debt ratio (DR)

Debt ratio is calculated as follows,

Debt ratio $(\mathrm{DR})=\frac{\text { Total liabilities }}{\text { Total assets }}$. 


\subsection{Gearing ratio (GR)}

Gearing ratio is calculated as follows,

Gearing ratio $(\mathrm{GR})=\frac{\text { Total noncurrent liabilities }}{\text { Total noncurrent liabilities }+ \text { Total equities }}$.

\subsection{Dependent variable: Economic value added}

Economic value added ratio is calculated as follows,

Economic value added ratio $=\frac{\text { Net profit }}{\text { Total equities } \times \text { average rate of saving }}$.

The proposed study of this paper considers a dummy variable as dependent variable named Company Type, which is one when Economic value added is above average and zero, otherwise. Therefore the proposed model of this paper is as follows,

Company type = f (CR, WCTA, QR, CFR, FCF1, FCF2, GR, DE, DR).

There are two hypotheses associated with the proposed study of this paper as follows,

1. There is a meaningful relationship between financial ratios and management risk of drug firms listed on Tehran Stock Exchange.

2. The proposed model of this paper maintains efficient capability on estimating the performance of firms, which are active on drug industry.

\section{The results}

We have used logistic regression technique to verify the relationship between independent variables and dependent variable. In our study, we have gathered the financial information from 29 selected firms listed on Tehran Stock Exchange on drug industry over the period 2006-2011. Table 1 shows details of our results.

Table 1

The results of regression analysis

\begin{tabular}{llll}
\hline Variable & Coefficient & Z-value & P-value \\
\hline CR & 1.288 & 1.262 & 0.207 \\
WCTA & 2.49 & 1.499 & 0.136 \\
QR & -2.24 & -1.804 & 0.071 \\
CFR & -19.85 & -3.179 & 0.001 \\
FCF1 & 2.549 & 2.302 & 0.021 \\
FCF2 & 12.45 & 1.929 & 0.054 \\
GR & -0.772 & -0.328 & 0.745 \\
DE & 0.145 & 0.876 & 0.381 \\
DR & 1.704 & 0.979 & 0.328 \\
Intercept & -1.417 & -0.809 & 0.418 \\
\hline
\end{tabular}

There are three indicators for validating logistic regression function, which are LR, McFaddenRsquared and H-L Statistic and the results of these statistics along with values are 24.426(0.001), 0.1399 and $8.1119(0.4226)$, respectively. The first indicator, LR, is statistically significance. 


\subsection{Testing the first hypothesis}

The first hypothesis of this survey investigates whether there is a meaningful relationship between independent variables and risk evaluation of receivable accounts. Table 2 summarizes some of the results as follows,

Table 2

The results of regression analysis for testing the first hypothesis

\begin{tabular}{llll}
\hline Variable & Coefficient & Z-value & P-value \\
\hline QR & -2.24 & -1.804 & 0.071 \\
CFR & -19.85 & -3.179 & 0.001 \\
FCF1 & 2.549 & 2.302 & 0.021 \\
FCF2 & 12.45 & 1.929 & 0.054 \\
\hline
\end{tabular}

As we can observe from the results of Table 2, all coefficients are statistically meaningful when the level of significance is ten percent and we can confirm the first hypothesis. Note that the first two variables, QR and CFR, influence the dependent variable negatively while the second two variables, FCF1 and FCF2, positively influence the dependent variable.

\subsection{Testing the second hypothesis}

The second hypothesis of this survey we try to find out how effective the proposed model of this paper works. Table 3 shows details of our investigation,

Table 3

The results of details investigation on the second hypothesis

\begin{tabular}{lccc}
\hline Item & Sum of Company type =1 & Sum of Company type $=0$ & Sum \\
\hline $\operatorname{Pr}($ Company Type=1) & 71 & 24 & 95 \\
$\operatorname{Pr}($ Company Type=0) & 10 & 34 & 44 \\
Sum & 81 & 58 & 139 \\
Total number of corrected forecasted & 71 & 34 & 105 \\
Percentage of corrected forecasted & $87.65 \%$ & $58.62 \%$ & $75.54 \%$ \\
\hline
\end{tabular}

According to the results of Table 3, the proposed model of this paper could The results of our survey indicate that the proposed model of this paper is capable of forecasting high profit firms with a probability of $87.5 \%, 58.62 \%$ is the likelihood of predicting less profitable firms and on average, the firm could forecast profitable firms for $75.54 \%$, successfully.

\section{Conclusion}

In this paper, we have presented an empirical investigation to study the relationship between financial ratios on financial performances of some firms, which were active in drug industry over the period of 2006-2011. The proposed study of this paper gathered some necessary information from official financial statements reported through Tehran Stock Exchange and using logistic regression method examined two hypotheses. Based on the results of regression function, we have confirmed that the proposed model of this paper could estimate risk of receivable accounts successfully. In other words, The results of our survey indicate that the proposed model of this paper is capable of forecasting high profit firms with a probability of $87.5 \%, 58.62 \%$ is the likelihood of predicting less profitable firms and on average, the firm could forecast profitable firms for $75.54 \%$, successfully. 


\section{References}

Aghasi, S., Hejazi, S., Faradonbeh, M., Javanbakht, A \& Faradonbeh, F. (2013). A study on the effect of interest rate on performance of stock exchange: A case study of Tehran Stock Exchange. Management Science Letters, 3(5), 1357-1362.

Dehaghani, M., Rostami, A., Faradonbeh, M., Faradonbeh, F \& Javanbakht, A. (2013). A study of the effect of change on ownership structure on enterprise value of privatized firms: Evidence from Tehran Stock Exchange. Management Science Letters, 3(5), 1459-1466.

Esfahani, K \& Ghasanfarymojarad, M. (2013). A study on the relationship between capital structure and the performance of production market: A case study of firms listed on Tehran Stock Exchange. Management Science Letters, 3(4), 1297-1306.

Hajnoori, A., Amiri, M \& Alimi, A. (2013). Forecasting stock price using grey-fuzzy technique and portfolio optimization by invasive weed optimization algorithm. Decision Science Letters, 2(3), 175-184.

Hassani, M \& Misaghi, M. (2013). A study on relationship between capital employed efficiency and operating cash flow: Evidence from Tehran Stock Exchange. Management Science Letters, 3(4), 1089-1094.

Emamgholipour, M., Bagheri, S., Mansourinia, E \& Arabi, A. (2013). A study on relationship between institutional investors and earnings management: Evidence from the Tehran Stock Exchange. Management Science Letters, 3(4), 1105-1112.

Valahzaghard, M \& Mirzamomen, M. (2013). The relationship between top management turnover with earnings management and default risk and earnings forecast error in the Tehran Stock Exchange. Management Science Letters, 3(4), 1273-1280. 